\title{
DIFFERENCE IN PATIENT QUALITY OF LIFE AFTER HIP ARTHROPLASTY WITH A MINIMALLY INVASIVE APPROACH OR CLASSIC APPROACH
}

\author{
Mirela Vučković ${ }^{1}$, Lana Ružić ${ }^{2}$, Anton Tudor ${ }^{1}$ and Ivana Šutić3 \\ ${ }^{1}$ Lovran Department of Orthopedic Surgery, School of Medicine, University of Rijeka, Lovran, Croatia; \\ ${ }^{2}$ Department of Kinesiologic Anthropology, Faculty of Kinesiology, University of Zagreb, Zagreb, Croatia; \\ ${ }^{3}$ Health Center of Primorje-Gorski Kotar County, Rijeka, Croatia
}

\begin{abstract}
SUMMARY - The increasing rate of orthopedic procedures, hip arthroplasty in particular, requires improvement of surgical techniques, as well as of the respective rehabilitation protocols. The aim of the study was to assess differences in the quality of life and incidence of limping eight years after total hip arthroplasty performed with a minimally invasive or classic approach. This cross-sectional study included 68 patients, i.e. 32 operated with classic approach and 36 with minimally invasive approach during 2011. The following parameters were observed: anthropometric measurements, history of comorbidity, subjective assessment of limping, and SF-36 questionnaire (Short Form Survey Instrument). SF-36 testing, which consists of 8 domains, showed that 5 domains of the quality of life were statistically significantly better in the minimally invasive group (level of significance $p<0.05$ ). These domains were role of limitation due to physical health $(\mathrm{p}=0.01)$, energy $(\mathrm{p}=0.02)$, social functioning $(p=0.02)$, pain $(p=0.02)$ and general health $(p=0.00)$. The minimally invasive group had a statistically significantly lower incidence of limping $(\mathrm{p}=0.032)$. Quality of life after hip replacement could be a decisive factor when choosing the type of orthopedic procedure. The higher number of limping patients in the classic approach group may have contributed to differences in the quality of life. In conclusion, the minimally invasive approach enables higher long-term quality of life and functional recovery.
\end{abstract}

Key words: Arthroplasty, hip replacement; Osteoarthritis; Quality of life; Transgluteal approach

\section{Introduction}

Worldwide, $10 \%$ of men and $18 \%$ of women over the age of 60 have one of the symptoms of osteoarthritis (OA). The prevalence of OA increases with age, so $13.9 \%$ of adults over 25 have clinical signs of $\mathrm{OA}$ on at least one joint, while $33.6 \%$ of adults over 65 have $\mathrm{OA}^{1}$. Total hip replacement is considered a $21^{\text {st }}$ century operation in orthopedics and at the same time the greatest orthopedic achievement ${ }^{2,3}$. In medicine, there

Correspondence to: Mirela Vučkovic, mag. physioth., Lovran Department of Orthopedic Surgery, School of Medicine, University of Rijeka, Šetalište Maršala Tita 1, HR-51415 Lovran, Croatia E-mail: vuckovic.mirela@gmail.com

Received July 17, 2020, accepted December 9, 2020 is the need for daily improvement of surgical techniques, as well as of the respective rehabilitation protocols. The scientific community is still divided whether the minimally invasive surgery (MIS) is a better surgical procedure compared to the classic approach. The benefits of the MIS include less postoperative pain, less perioperative blood loss, earlier hospital discharge, and shorter length of incision ${ }^{4-6}$. As opposed to that, some groups of scientists believe that there is still less complications after classic approach ${ }^{7,8}$. Anterolateral muscle sparing surgery is basically a modification of the classic Watson-Jones approach. A key feature of the anterolateral operative approach is that the hip joint is accessed between the middle gluteal muscle and tensor muscle of fascia lata, i.e. muscle grips are not dissected ${ }^{9}$. 
The primary goal of total hip replacement is to enable performing activity of daily life without pain. In general, the level of daily activity varies according to gender, age, occupation, level of education, and other factors ${ }^{10}$. The level of physical activity that depends on the person's mobility can also be crucial for the quality of life, which has often been the subject of research in recent decades, both in clinical medicine and in many other scientific fields. Although the concept of the quality of life is known to everyone, there is no unique definition of it. Thus, for example, according to the World Health Organization, quality of life is viewed as an individual's perception of their own position in life in the context of the culture and value systems in which they live and in relation to their expectations, life goals, standards and concerns ${ }^{11}$. Cummins divides quality of life into seven relevant domains related to the individual experience of the quality of life, i.e. health, material well-being, productivity, intimacy, security, place in society, and mental well-being ${ }^{12}$. In some other scientific research, quality of life consists of at least three broad domains, i.e. physical domain (physical health), mental domain (mental health), and social domain (social activities). In an orthopedic patient, linking quality of life and functionality in the activities of everyday life is indispensable in the process of rehabilitation. After total hip replacement, one of the goals of rehabilitation is return to the same or higher level of quality of life that the patient had before operation, but with less pain. Konopka et al. assessed 12,784 patients having artificial hip or knee joint implanted and concluded that this operation did not only reduce pain but also increased the patient quality of life ${ }^{13}$. Similarly, Wilson et al. consider endoprosthesis implantation as the procedures that provide greatest quality of life improvement ${ }^{14}$. However, in the literature, there are almost no studies that compare the quality of life domain after MIS and classic approach to the hip joint replacement, especially not after a long period elapsed from the operation.

Limping in the hip joint is a very common symptom of degenerative hip disease that may sometimes persist even after total hip replacement. It can significantly affect the quality of life. Limping occurs due to asymmetric use of legs, which indicates that the function of normal gait is disturbed. It can be a symptom of a number of causes such as pain, structural abnormalities (different limb lengths, coxa vara and coxa valga, contractures), neuromuscular pathology, tumors, infections, trauma, congenital and developmental diseases ${ }^{9}$. Patients during walk often shorten the stance phase on the operated leg and with body position transfer the mass center to the ipsilateral hip to relieve load on the joint, which significantly disrupts the kinematic chain.

The aim of this study was to assess differences in the quality of life and incidence of limping eight years after total hip arthroplasty performed with MIS or classic approach, and also to determine the severity of limping.

\section{Patients and Methods}

The research was conducted at the Lovran Department of Orthopedic Surgery in 2019. The 6-month cross-sectional study was approved by the institutional Ethics Committee. The study included 68 patients having undergone elective surgery of hip replacement in 2011. Patients were called by phone for check-up by orthopedic specialist and physiotherapist. They signed a written consent and were informed that the data would be published only as mean values, protecting their personal data. All tests were performed by the same physiotherapist. Initially, a total of 102 patients were contacted, yielding a $66 \%$ response rate. Since the subjects were from all over the Republic of Croatia and were called 8 years after the operation, many phone numbers had changed and invitation was sent them by post. The most common reasons for dropping out were severe illness, infections, inability to contact patients, patients were unable to come on appointment, patients did not want to attend the check-up even though they were successfully contacted, and patient age. Namely, in 2019, some of them were aged over 85 and could not travel from their place of residence. The response rate was comparable in patients operated on with minimally invasive method and those operated on with classic approach. Out of 68 patients included in the study, 45 patients did not have endoprosthesis implant on the other joint besides the operated one, while 20 patients had artificial hip joint implanted on the opposite side (with classic approach in eight patients and with MIS in 12 patients). One patient in the MIS group had artificial knee joint implanted, whereas two patients had undergone hip reoperation (one in each group). 
Data were collected by conducting anthropometric measurements, taking detailed history in terms of comorbidity, subjective assessment of limping, and completing the Short Form Survey Instrument (SF-36) questionnaire. This questionnaire has been translated into different languages, including Croatian, and its metric characteristics are satisfactory. It is proven to be very applicable in the evaluation of the quality of life of orthopedic patients, as well as in many other scientific fields ${ }^{15,16}$. SF-36 is a questionnaire used to assess general condition of subjects, which consists of 36 questions distributed in eight domains, as follows: physical functioning, limitation due to physical problems, limitations due to emotional problems, social functioning, mental health, vitality and energy, physical pain, and general health perception. The result is expressed as a standardized value in the range of $0-100$ for each health dimension. A higher score indicates better result $t^{17,18}$. Detailed history in terms of comorbidity was included due to potential diseases and conditions that could have influenced the operation outcome. Assessment of the degree of limping was performed clinically. Patients were asked to walk around in the infirmary in order to establish a disorder of gait biomechanics by observation. The results were categorized into three categories, where walking without visible signs of limping was marked as 0 , walking with mild limping as 1 , and walking with pronounced limping as 2 .

\section{Statistics}

Data were analyzed by Statistica software, version 13.5.0.17, 1984-2018 (TIBCO Software Inc., Zagreb, Croatia). Central tendency (mean, standard deviation, minimum, maximum and range) and measures of asymmetric distribution (skewness) and elongation (kurtosis) were calculated for all continuous variables, in separate for the group operated on by classic approach and the group operated on by MIS. The level of statistical significance was set at $p<0.05$. The exact research power was calculated using the free $G$ Power software package for the main results. Post hoc test was used to calculate the effect size of 0.72 and the exact power of 0.89 for the variable limitation due to physical problems; effect size of 0.60 and power 0.77 for the energy level variable; effect size of 0.73 and power of 0.89 were the same for the variable of social functioning and perception of general health. Slightly lower values were found only in the pain variable (power 0.63 and effect size 0.5). Student's t-test for independent samples was used to test whether the groups differed according to age and body mass index (BMI). The number and proportion of comorbidities in patients were expressed in frequency tables. The $\chi^{2}-$ test was used to determine if there was difference between the groups in comorbidity and incidence of limping. With descriptive data provided, non-parametric Mann Whitney U test was employed to determine differences in the SF-36 questionnaire responses between the groups operated on by the MIS and classic approach.

\section{Results}

Out of a total of 68 patients, 32 patients were operated on by the classic approach, while 36 patients were operated on by MIS. Classic approach was used in eight male and 24 female patients, whereas MIS was used in 12 male and 24 female patients (Table 1). Measures of central tendency, asymmetry and elongation of the distribution are presented for each group separately in Table 2.

Table 1. Number and percentage of patients according to type of surgical procedure and gender (frequency table)

\begin{tabular}{|l|l|l|l|}
\hline $\begin{array}{l}\text { Surgical } \\
\text { procedure }\end{array}$ & Male & Female & Total \\
\hline CLA & 8 & 24 & $32(47.06 \%)$ \\
MIS & 12 & 24 & $36(52.94 \%)$ \\
Total & $20(29.41)$ & $48(70.59 \%)$ & $68(100 \%)$ \\
\hline
\end{tabular}

CLA = classic approach; MIS = minimally invasive surgery

The patient mean age was $69.00 \pm 7.65$ (range 40 84 ; median 70) years. A precondition for further analysis was also related to the assumption that the groups differed according to age and BMI because this could influence responses and cause bias. Student's t-test for independent samples showed that the two groups did not differ according to age $(p=0.269)$ and BMI $(\mathrm{p}=0.149)$.

Analysis of responses to the SF-36 questionnaire consisting of 8 domains using Mann-Whitney U test showed that in 5 domains better result was recorded in patients operated on by MIS, with a significance level 
Table 2. Analysis of indicator value of descriptive parameters of age and morphological variables

\begin{tabular}{|l|l|l|l|l|l|l|l|}
\hline & Mean & Median & Minimum & Maximum & SD & Skew & Kurt \\
\hline Age $(\mathrm{yrs})$ & & & & & & & \\
CLA & 67.90 & 69.50 & 40.00 & 80.00 & 8.17 & -1.23 & 2.96 \\
MIS & 69.97 & 70.50 & 54.00 & 84.00 & 7.13 & -0.41 & -0.32 \\
\hline BM $(\mathrm{kg})$ & & & & & & & \\
CLA & 79.65 & 80.00 & 53.00 & 116.00 & 14.76 & 0.18 & -0.13 \\
MIS & 83.11 & 82.50 & 52.00 & 115.00 & 14.33 & 0.09 & -0.11 \\
\hline BH $(\mathrm{cm})$ & & & & & & & \\
CLA & 169.28 & 167.50 & 158.00 & 190.00 & 8.75 & 0.77 & -0.10 \\
MIS & 168.33 & 166.50 & 150.00 & 188.00 & 8.87 & 0.48 & -0.16 \\
\hline BMI $\left(\mathrm{kg} / \mathrm{m}^{2}\right)$ & & & & & & & \\
CLA & 27.40 & 27.00 & 20.00 & 38.00 & 4.38 & 0.46 & -0.03 \\
MIS & 29.00 & 29.00 & 19.00 & 44.00 & 4.59 & 0.76 & 2.16 \\
\hline
\end{tabular}

$\mathrm{SD}$ = standard deviation; $\mathrm{BM}$ = body mass; $\mathrm{BH}$ = body height; $\mathrm{BMI}=$ body mass index CLA = classic approach; $\mathrm{MIS}=$ minimally invasive surgery; Skew = skewness; Kurt = kurtosis

Table 3. Comparison of $S F-36$ test results in patients operated on by CLA and MIS

\begin{tabular}{|l|l|l|l|l|}
\hline SF-36 & $\begin{array}{l}\text { CLA } \Sigma \\
\text { Range }\end{array}$ & $\begin{array}{l}\text { MIS } \Sigma \\
\text { Range }\end{array}$ & U & p-value \\
\hline PH F & 969.5 & 1376.5 & 441.5 & 0.10 \\
PH LIM & 898.0 & 1448.0 & 370.0 & $0.01^{*}$ \\
E LIM & 1109.0 & 1237.0 & 571.0 & 0.96 \\
ENERGY & 922.5 & 1423.5 & 394.5 & $0.03^{*}$ \\
MH & 947.5 & 1398.5 & 419.5 & 0.05 \\
SF & 896.0 & 1450.0 & 368.0 & $0.02^{*}$ \\
PAIN & 924.5 & 1421.5 & 396.5 & $0.02^{*}$ \\
GH & 876.5 & 1469.5 & 348.5 & $0.00^{*}$ \\
\hline
\end{tabular}

CLA = classic approach; MIS = minimally invasive surgery; $\mathrm{PH} \mathrm{F}$ = physical functioning; $\mathrm{PH}$ LIM = role limitation due to physical problems; $\mathrm{E}$ LIM = role limitation due to emotional problems; $\mathrm{MH}$ = mental health; $\mathrm{SF}$ = social functioning; $\mathrm{PAIN}$ = body pain; $\mathrm{GH}=$ general health; *statistically significant

of $\mathrm{p}<0.05$. These domains were limitation due to physical problems $(\mathrm{p}=0.01)$, energy level $(\mathrm{p}=0.03)$, social functioning $(\mathrm{p}=0.02)$, pain $(\mathrm{p}=0.02)$ and general health perception $(\mathrm{p}=0.00)$. For the domains of physical functioning $(\mathrm{p}=0.09)$, limitation due to emotional problems $(\mathrm{p}=0.09)$ and vitality/energy $(\mathrm{p}=0.05)$, there were no between-group differences (Table 3 ).

The number and type of comorbidities in study patients are shown in Table 4 . The $\chi^{2}$-test showed no statistically significant difference in the rate of comorbidities between the groups $(\mathrm{p}=0.748)$. The number of
Table 4. Number and percentage of patients with particular comorbidities

\begin{tabular}{|l|l|l|}
\hline Comorbidity & $\mathrm{n}$ & Percentage \\
\hline Without comorbidity & 28 & $41 \%$ \\
Hypertension & 12 & $18 \%$ \\
Angina pectoris & 1 & $2 \%$ \\
Diabetes & 2 & $3 \%$ \\
Cardiac stent & 1 & $1 \%$ \\
Cancer & 1 & $1 \%$ \\
Pulmonary embolism & 1 & $1 \%$ \\
Minor surgical procedures & 3 & $4 \%$ \\
Cholecystectomy & 1 & $2 \%$ \\
2 comorbidities & 16 & $24 \%$ \\
3 comorbidities & 2 & $3 \%$ \\
& 68 & $100 \%$ \\
\hline
\end{tabular}

These figures were similar in both groups; therefore it is shown collectively (frequency table).

patients without comorbidities was also equal in the two groups and $\chi^{2}$-test yielded no statistically significant difference $(\mathrm{p}=0.673)$.

Differences in the number of patients with disturbed normal gait biomechanics are listed in Table 5. The $\chi^{2}$-test showed the presence of limping to be statistically significantly more common in the group operated on by classic approach compared to those with MIS ( $p=0.032)$; however, there was no difference in the degree of limping between those with limping from the two groups $(\mathrm{p}=0.879)$. 
Table 5. Patient distribution according to the degree of limping

\begin{tabular}{|l|l|l|l|l|l|}
\hline Approach & Without limping & Limping & & Mild limping & Pronounced limping \\
\cline { 1 - 3 } CLA & 15 & 17 & & 14 & 3 \\
MIS & 26 & 10 & & 8 & 2 \\
\hline$\chi^{2}$-test & $\mathrm{p}=0.032$ & & $\mathrm{p}=0.879$ \\
\hline
\end{tabular}

CLA = classic approach; MIS = minimally invasive surgery

\section{Discussion}

The most important result in this research lies in the fact that in certain aspects, better quality of life was found in several domains in patients operated on with MIS compared to classic approach. Also, patients operated on with MIS had a lower rate of limping compared to patients operated on with classic approach. In the latter, muscle damage is inevitable compared to the former, which may have been manifested through a higher degree of limping 8 years after surgery in the group operated on by classic approach.

On SF-36 questionnaire analysis, the domains being researched can be viewed through physical, mental and social functioning, all through patient personal perception. It is important to note that patients operated on by MIS feel less limitations due to physical problems, and therefore feel more capable and have higher self-assessed energy levels. Therefore, patients operated on with MIS limp less, consequently having more energy-efficient gait and less physical limitations. The activities of daily life probably are performed much more easily than in the group operated on by classic approach.

Minimally invasive approach is more sparing for abductor muscles, and strong pelvitrochanteric muscles are an important part of the functional unit we need for energy-efficient gait. It is known that damage to the joint capsule, ligaments and muscles leads to disturbed static and dynamic stability of the joint, which can result in a fall. A small number of studies compared results of rehabilitation between these surgical approaches at long-term follow-up. A complex longitudinal study of two patient groups operated on with these approaches was performed at the Lovran Department of Orthopedic Surgery three years after hip surgery and found the majority of motor skill results to be in favor of the MIS group (range of motion, abductor strength, gait speed and general motor skills $)^{19}$. Unfortunately, patient quality of life was not assessed. In contrast, a study by Reichert et al. in 123 patients 12 months after surgery indicated the advantage of MIS over classic one; analyzing SF-36 questionnaire, they found a significant difference in the domain of physical functioning ${ }^{20}$, which is partly different from the results obtained in our study. Tudor $e t$ $a l .{ }^{19}$ and Reichert et al. ${ }^{20}$ report on the advantages of MIS in the early phase of recovery; the peculiarity of our research was a longer period of time that had elapsed from the surgery, i.e. eight years. Opinions in the scientific community about advantages of MIS over classic approach are still contradictory, although those in favor of MIS slightly prevail. It is interesting that despite the dilemma among scientists, a small number of studies investigated these approaches over a longer period of time. There are similar studies that monitored surgery outcome through the quality of life domain after a number of years of the surgery, but they were mostly conducted after artificial hip joint implantation by one type of surgery and were not comparative ${ }^{21,22}$. Galea et al. ${ }^{23}$ conducted an international follow-up study of patients after total hip replacement, i.e. cement prosthesis, at four follow-up time points over a 7-year period involving 976 patients. The mental dimension (limitation due to emotional problems) showed that it was largely connected to the incidence of pain in patients, both on the joint operated on and on the contralateral joint. In the same study, it was pointed out that overweight patients had greater limitation of daily physical function. This was the reason to include BMI in the data collection process in our study. There was no initial difference in BMI between the groups. The potential effect of BMI on general functional mobility was excluded, which could have possibly influenced the study end results.

Differences in pain sensation may have also caused differences in the mental domain. Pain is very often associated with a feeling of poor general condition. 
Similar to the studies by Galea et al. ${ }^{23}$ and Wiklund and Romanus ${ }^{24}$, patients having undergone MIS reported less pain compared to those operated on by classic approach, in our study even 8 years after surgery. It must have influenced other domains, i.e. energy levels, social function and perception of general health.

If, by definition, health is a state of good physical, mental and social well-being, and these domains have been shown to be better in patients from the MIS group, it could be concluded that MIS has more health benefits as regards pain after surgery, rehabilitation potential, and overall satisfaction of patients as compared to classic approach.

This cross-sectional study had several methodologic limitations. The first was the impossibility of influencing the process of randomization of patients who responded to the call. Another limitation of the study was the lack of an accurate insight into the factors that may have influenced patient response. Since the number of responders was the same in both groups, it was presumed that these factors were equally present in the two groups and did not affect the results obtained. Another limitation of the study was the fact that the degree of limping was assessed by experts but not exactly measured. In this area, additional research complemented with objective gait analysis instruments or electromyography is needed. It should be conducted in collaboration with other institutions that perform these surgeries in order to include a larger patient sample.

\section{Conclusion}

This research confirmed that MIS affects maintenance of long-term quality of life. Patients operated on with MIS have a lower incidence of limping than patients operated on with classic approach. Sometimes the cost of recovery is not taken in consideration and more expensive procedures are unfairly avoided, although ultimately, they would probably be more economical for the community due to the speed of recovery and above all more beneficial for patients. This research also suggests that we should insist on the strength and power of the pelvitrochanteric muscles and all kinetic chain after total hip replacement, primarily after classic approach, in order to reduce the possibility of limping even after a long period of time.

\section{References}

1. Barr AJ, Campbell TM, Hopkinson D, Kingsbury SR, Bowes MA, Conaghan PG. A systematic review of the relationship between subchondral bone features, pain and structural pathology in peripheral joint osteoarthritis. Arthritis Res Ther. 2015;17(1):228. doi: 10.1186/s13075-015-0735-x

2. Gluck T. Die Invaginationsmethode der Osteo- und Arthroplastik. Berl Klin Wochenschr. 1890;28:732-6.

3. Smith-Petersen M. Evolution of mould arthroplasty of the hip joint. J Bone Joint Surg Br. 1948;30:59-75.

4. Bertin KC, Rottinger H. Anterolateral mini-incision hip replacement surgery: a modified Watson-Jones approach. Clin Orthop Relat Res. 2004;248-55. doi: 10.1097/01.blo.0000 150294.81825.8c

5. Dorr LD, Maheshwari AV, Long WT, Wan Z, Sirianni LE. Early pain relief and function after posterior minimally invasive and conventional total hip arthroplasty. A prospective, randomized, blinded study. J Bone Joint Surg Am. 2007;89:115360. doi: 10.2106/JBJS.F.00940

6. Gravius S, Wirtz DC, Maus U, Andereya S, Muller-Rath R, Mumme T. Minimally invasive approaches to the hip joint for total hip arthroplasty: state of the art within the scope of the OrthoMIT project for the development of an integrated platform for smart interventional orthopaedic surgery and traumatology. Z Orthop Unfall. 2007;145:608-14. doi: 10.1055 /s-2007-965691

7. Mow CS, Woolson ST, Ngarmukos SG,Park EH, Lorenz HP. Comparison of scars from total hip replacements done with a standard or a mini-incision. Clin Orthop Relat Res. 2005; 441:80-5. doi: 10.1097/01.blo.0000191317.85422.c3

8. Woolson ST, Mow CS, Syquia JF, Lannin JV, Schurman DJ Comparison of primary total hip replacements performed with a standard incision or a mini-incision. J Bone Joint Surg Am. 2004;86A:1353-8. doi: 10.2106/00004623-200407000-00001

9. Tudor A, Mađarević T. Kuk. Zagreb: Medicinska naklada; 2018. p 261-6. (in Croatian)

10. Meessen JMTA, Peter WF, Wolterbeek R, Cannegieter SC, Tilbury C, Bénard MR, et al. Patients who underwent total hip or knee arthroplasty are more physically active than the general Dutch population. Rheumatol Int. 2017;37(2):219-27. doi: 10.1007/s00296-016-3598-9

11. World Health Organization Quality of Life Group. The World Health Organization quality of life assessment (WHOQOL$\mathrm{BREF}$ ): Introduction, administration, scoring and generic version of the assessment; Field trial version. Geneva: Programme on Mental Health, 1996.

12. Cummins RA. Comprehensive Quality of Life Scale for Adults. $4^{\text {th }}$ Edition. Melbourne: School of Psychology, Deakin University; 1993.

13. Konopka JF, Lee YY, Su EP, McLawhorn AS. Quality-adjusted life years after hip and knee arthroplasty: health-related quality of life after 12,782 joint replacements. JBJS Open Access. 2018;3(3):e0007. doi: 10.2106/JBJS.OA.18.00007 
14. Wilson I, Bohm E, Lübbeke A, Lyman S, Overgaard S, Rolfson O, Dunbar M. Orthopaedic registries with patient-reported outcome measures. EFORT Open Rev. 2019;4(6):357-67. doi: 10.1302/2058-5241.4.180080

15. Martinec R, Pinjatela R, Balen D. Quality of life in patients with rheumatoid arthritis - a preliminary study. Acta Clin Croat. 2019;58(1):157-66. doi: 10.20471/acc.2019.58.01.20

16. Gok Ugur H, Erci B. The effect of home care for stroke patients and education of caregivers on the caregiver burden and quality of life. Acta Clin Croat. 2019;58(2):321-32. doi: 10.20471/ acc.2019.58.02.16

17. Maslić Seršić D, Vuletić G. Psychometric evaluation and establishing norms of Croatian SF-36 Health Survey: framework for subjective health research. Croat Med J. 2006;47(1):95-102.

18. Gladović N, Zavoreo I, Trošt Bobić T, Bašić Kes V. Razlike u učinkovitosti standardnog fizikalnog tretmana u odnosu na manualnu terapiju tehnikom yumeibo i vježbama u bolesnika s kroničnom nespecifičnom križoboljom. Acta Med Croatica. 2019;73(2):159-65. (in Croatian)

19. Tudor A, Ruzic L, Vuckovic M, Prpic T, Rakovac I, Mađarevic $\mathrm{T}$, et al. Functional recovery after muscle sparing total hip arthroplasty in comparison to classic lateral approach - a threeyear follow-up study. J Orthop Sci. 2016;21(2):184-90. doi: 10.1016/j.jos.2015.12.010
20. Reichert JC, von Rottkay E, Roth F, Renz T, Hausmann J, Kranz J, et al. A prospective randomized comparison of the minimally invasive direct anterior and the transgluteal approach for primary total hip arthroplasty. BMC Musculoskelet Disord. 2018;19(1):241. doi: 10.1186/s12891-018-2133-4

21. Quintana JM, Escobar A, Aguirre U, Lafuente I, Arenaza JC. Predictors of health-related quality-of-life change after total hip arthroplasty. Clin Orthop Relat Res. 2009;467(11):288694. doi: 10.1007/s11999-009-0868-9

22. Mariconda M, Galasso O, Costa GG, Recano P, Cerbasi S. Quality of life and functionality after total hip arthroplasty: a long-term follow-up study. BMC Musculoskelet Disord. 2011;12:222. doi: 10.1186/1471-2474-12-222

23. Galea VP, Rojanasopondist P, Ingelsrud LH, Rubash HE, Bragdon C, Huddleston JI, et al. Longitudinal changes in patient-reported outcome measures following total hip arthroplasty and predictors of deterioration during follow-up: a seven-year prospective international multicentre study. Bone Joint J. 2019;768-78. doi: 10.1302/0301-620 X. 101 B7.BJJ-20181491.R1

24. Wiklund I, Romanus B. A comparison of quality of life before and after arthroplasty in patients who had arthrosis of the hip joint. Bone Joint J. 1991;73(5):765-9.

\title{
RAZLIKA U KVALITETI ŽIVOTA NAKON ARTROPLASTIKE ZGLOBA KUKA MINIMALNO INVAZIVNIM PRISTUPOM ILI KLASIČNIM PRISTUPOM
}

\author{
M. Vučkovic, L. Ružič, A. Tudor i I. Šutić
}

Sve veća učestalost ortopedskih zahvata, osobito artroplastike kuka, zahtijeva unaprjeđenje kirurških i rehabilitacijskih protokola. Cilj istraživanja bio je ispitati razlike u kvaliteti života i incidenciji šepanja osam godina nakon artroplastike zgloba kuka u bolesnika operiranih minimalno invazivnim ili klasičnim pristupom. Provedeno je presječno istraživanje na 68 bolesnika, tj. 32 operirana klasičnim pristupom i 36 minimalno invazivnim pristupom ugradnje umjetnog zgloba kuka tijekom 2011. godine. Proučavali smo antropometrijske mjere, anamnestičke podatke o komorbiditetima, subjektivne procjene šepanja i popunjavanje standardnog upitnika za procjenu kvalitete života, SF-36 (Short Form Survey Instrument). Analizirajući odgovore na SF-36 upitnik koji sadrži 8 domena, kvaliteta života je u pet domena bila statistički značajno bolja kod bolesnika operiranih minimalno invazivnim pristupom: ograničenje zbog tjelesnih poteškoća $(\mathrm{p}=0,01)$, razina energije $(\mathrm{p}=0,02)$, socijalno funkcioniranje $(\mathrm{p}=0,02)$, bol $(\mathrm{p}=0,02)$ i percepcija općeg zdravlja $(\mathrm{p}=0,00)$. U skupini s minimalno invazivnim pristupom šepanje je bilo statistički značajno manje prisutno $(\mathrm{p}=0,032)$. Kvaliteta života nakon operativnog zahvata trebala bi biti glavni kriterij u izboru operacijskog pristupa. Veći broj bolesnika koji šepaju u skupini operiranoj klasičnim pristupom u odnosu na minimalno invazivni pristup možda također doprinosi razlici u kvaliteti života. U zaključku, minimalno invazivni pristup omogućava dugoročno održavanje više razine kvalitete života i bolji oporavak.

Ključne riječi: Artroplastika zgloba kuka; Kvaliteta života; Osteoartritis; Transglutealni pristup 